\title{
HUBUNGAN TINGKAT PENDIDIKAN, TINGKAT SOSIAL EKONOMI DAN TINGKAT PENGETAHUAN ORANGTUA TENTANG PERAWATAN GIGI DENGAN KEJADIAN KARIES GIGI PADA ANAK USIA BALITA DI DESA MANCASAN BAKI SUKOHARJO
}

\author{
Rahayu Setyaningsih ${ }^{1}$, Irfan Prakoso ${ }^{2}$
}

\begin{abstract}
Background: Dental abnormalities are often found in preschool children is dental caries (cavities), since in general the state of children's oral hygiene is worse and more children eating food and drinks that cause caries than adults. The role of parents is indispensable in maintaining the health of children, especially dental and oral hygiene for children of preschool age are still dependent on their parents.

The Purpose : to determine the relationship between the level of education, socioeconomic level and the level of parental knowledge about dental treatment with the incidence of dental caries in children under five year"s in the village Mancasan.

Subjects: The population in this study were all parents in Mancasan village who have toddlers as many as 50 people. The sample in this study used a sampling technique total sampling.

Methods: This research is an analytical research design correlation to determine the relationship between the level of education, socioeconomic level and the level of parental knowledge about dental care

Results: the results of multivariate statistical test values obtained Nagelkerke $R$ Square of $47.3 \%$

Conclusion: a variable level of education, socioeconomic level and the level of knowledge together can influence the incidence of dental caries in children under five years of $47.3 \%$ and the remaining $52.7 \%$ influenced by other variables.
\end{abstract}

Keywords: Education level, social economy, the level of knowledge, Dental Caries

\section{PENDAHULUAN}

Kelainan gigi yang sering dijumpai pada anak prasekolah adalah karies gigi (gigi berlubang), karena pada umumnya keadaan kebersihan mulut anak lebih buruk dan anak lebih banyak makan-makanan serta minuman yang menyebabkan karies dibanding orang dewasa. Peran orang tua sangat diperlukan dalam pemeliharaan kesehatan anak, khususnya kebersihan gigi dan mulut karena anak usia prasekolah masih bergantung pada orang tua.
Orang tua mempunyai kewajiban dalam menjaga kebersihan gigi pada anak dan pada masa ini, berbagai masalah kesehatan dapat terjadi pada anak usia prasekolah, salah satunya adalah karies gigi atau yang biasanya dikenal gigi berlubang.

Prevalensi nasional masalah gigi dan mulut adalah 25,9 persen, sebanyak 14 provinsi mempunyai prevalensi masalah gigi dan mulut di atas angka nasional. Secara keseluruhan kemampuan untuk mendapatkan pelayanan dari tenaga 
medis gigi sebesar 8,1 persen EMD (Effective Medical Demand). Ditemukan EMD meningkat pada kelompok umur yang lebih tinggi umur 45-54 tahun meningkat (EMD:10,6 dibanding EMD umur 12 tahun: 7,0$)$, EMD di perkotaan $(8,6)$ lebih besar dari EMD perdesaan $(7,5)$, dan EMD meningkat pada status ekonomi lebih tinggi (EMD teratas: 9,0). Prevalensi nasional menyikat gigi setiap hari adalah 94,2 persen sebanyak 15 provinsi berada dibawah prevalensi nasional.

Untuk perilaku benar dalam menyikat gigi berkaitan dengan faktor gender, ekonomi, dan daerah tempat tinggal. Ditemukan sebagian besar penduduk Indonesia menyikat gigi pada saat mandi pagi maupun mandi sore, $(76,6 \%)$.

Berdasarkan hasil wawancara pada 10 ibu yang memiliki anak usia balita, 6 ibu mengharuskan anaknya menggosok gigi dan 4 ibu tidak mengharuskan anaknya gosok gigi dikarenakan anaknya yang rewel dan 4 anak yang rewel tersebut mengalami karies gigi. Orangtua belum mengetahui bagaimana cara merawat gigi anak yang benar. Berdasarkan hal tersebut peneliti tertarik untuk mengetahui "Hubungan antara Tingkat Pendidikan, Tingkat Sosial Ekonomi dan Tingkat Pengetahuan Orangtua tentang Perawatan Gigi dengan Kejadian Karies Gigi pada Anak Usia Balita di Desa Mancasan".

\section{TUJUAN PENELITIAN}

Mengetahui hubungan antara tingkat pendidikan, tingkat sosial ekonomi dan tingkat pengetahuan orangtua tentang perawatan gigi dengan kejadian karies gigi pada anak usia balita di Desa Mancasan.

\section{DESAIN PENELITIAN}

Penelitian ini merupakan penelitian analitik dengan desain korelasi untuk mengetahui hubungan antara tingkat pendidikan, tingkat sosial ekonomi dan tingkat pengetahuan orangtua tentang perawatan gigi sebagai variabel bebas (independent variable) dengan kejadian karies gigi pada anak usia balita sebagai variabel terikat (dependent variable).

\section{POPULASI, SAMPEL, DAN TEHNIK SAMPLING}

Populasi pada penelitian ini adalah seluruh orangtua yang ada di Desa Mancasan yang mempunyai balita sebanyak 50 orang.

Sampel dalam penelitian ini adalah orangtua yang mempunyai anak balita di Desa Mancasan sebanyak 50 orang.

Dalam penelitian ini peneliti menggunakan teknik sampling jenuh atau total sampling.

\section{HASIL PENELITIAN}

Dibawah ini akan dipaparkan karakteristik responden orangtua berdasarkan jenis kelamin, pendidikan, pekerjaan, pendapatan dan karakteristik balita berdasarkan jenis kelamin dan umur sebagai berikut:

1. Karakteristik responden orangtua

a. Berdasarkan jenis kelamin

Tabel 1

\begin{tabular}{ccc}
\hline Jns Klmin & $f$ & $(\%)$ \\
\hline Laki-laki & 9 & 18 \\
\hline Perempuan & 41 & 82 \\
\hline Jumlah & 50 & 100 \\
\hline
\end{tabular}

Dari tabel di atas diperoleh informasi bahwa 41 responden $(82 \%)$ berjenis kelamin perempuan dan 9 responden (18\%) adalah berjenis kelamin laki-laki. 
b. Berdasarkan umur

Tabel 2

\begin{tabular}{ccc}
\hline $\begin{array}{c}\text { Umur } \\
\text { (Tahun) }\end{array}$ & $\mathrm{f}$ & $(\%)$ \\
\hline $25-30$ & 26 & 52 \\
\hline $31-35$ & 11 & 22 \\
\hline $36-40$ & 4 & 8 \\
\hline $41-45$ & 6 & 12 \\
\hline $46-50$ & 2 & 4 \\
\hline $51-55$ & 1 & 2 \\
\hline Jumlah & 50 & 100 \\
\hline
\end{tabular}

Dari tabel di atas diperoleh informasi bahwa jumlah responden terbanyak adalah usia 25 - 30 tahun yaitu 26 orang (52\%), dan jumlah responden paling sedikit usia 51 - 55 tahun yaitu 1 orang (2\%).

\section{c. Berdasarkan pendidikan}

Tabel 3

\begin{tabular}{ccc}
\hline Pendidikan & $\mathrm{f}$ & $(\%)$ \\
\hline SD & 5 & 10 \\
\hline SMP & 29 & 58 \\
\hline SMA & 12 & 24 \\
\hline Diploma & 1 & 2 \\
\hline Sarjana & 3 & 6 \\
\hline Jumlah & 50 & 100 \\
\hline
\end{tabular}

Dari tabel di atas diperoleh informasi bahwa jumlah responden terbanyak adalah berpendidikan SMP yaitu 29 orang (58\%), dan jumlah responden paling sedikit berpendidikan diploma yaitu 1 orang (2\%)

\section{d. Berdasarkan pendapatan perbulan}

Tabel 4

\begin{tabular}{ccc}
\hline Pendapatan & $\mathrm{f}$ & $(\%)$ \\
\hline$<2$ juta & 41 & 82 \\
\hline$>2$ juta & 9 & 18 \\
\hline Jumlah & 50 & 100 \\
\hline
\end{tabular}

Dari tabel di atas diperoleh informasi bahwa jumlah responden yang terbanyak adalah dengan pendapatan kurang dari 2 juta rupiah perbulan yaitu 41 orang (82\%), dan jumlah responden dengan pendapatan di atas 2 juta rupiah perbulan adalah 9 orang (18\%).

\section{e. Berdasarkan pekerjaan}

Tabel 5

\begin{tabular}{ccc}
\hline Pekerjaan & $\mathrm{f}$ & $(\%)$ \\
\hline Wiraswasta & 18 & 36 \\
\hline IRT & 14 & 28 \\
\hline Buruh & 11 & 22 \\
\hline Guru & 4 & 8 \\
\hline Pedagang & 2 & 4 \\
\hline Perawat & 1 & 2 \\
\hline Jumlah & 50 & 100 \\
\hline
\end{tabular}

Dari tabel di atas diperoleh informasi bahwa jumlah responden yang terbanyak adalah bekerja sebagai wiraswasta yaitu 18 orang (36\%), dan responden paling sedikit bekerja sebagai perawat yaitu sebanyak 1 orang $(2 \%)$.

2. Karakteristik balita

a. Berdasarkan jenis kelamin

Tabel 6

\begin{tabular}{ccc}
\hline Jns Klmin & $\mathrm{f}$ & $(\%)$ \\
\hline Laki-laki & 23 & 46 \\
\hline Perempuan & 27 & 54 \\
\hline Jumlah & 50 & 100 \\
\hline
\end{tabular}

Dari tabel di atas diperoleh informasi bahwa 23 balita (46\%) berjenis kelamin laki-laki dan 27 balita (54\%) berjenis kelamin perempuan.

b. Berdasarkan usia

Tabel 7

\begin{tabular}{c|c|c}
\hline $\begin{array}{c}\text { Usia } \\
\text { (Tahun) }\end{array}$ & $\mathrm{f}$ & $(\%)$ \\
\hline $1-3$ & 16 & 32 \\
\hline $4-5$ & 34 & 68 \\
\hline Jumlah & 50 & 100 \\
\hline
\end{tabular}


Dari tabel di atas diperoleh informasi bahwa jumlah balita yang terbanyak adalah usia 4-5 tahun yaitu 34 orang (68\%), dan balita sebanyak 16 orang (32\%) berusia 1-3 tahun.

3. Hasil penelitian

a. Variabel tingkat pendidikan

Tabel 8

\begin{tabular}{c|c|c}
\hline $\begin{array}{c}\text { Tingkat } \\
\text { Pendidikan }\end{array}$ & $\mathrm{f}$ & $(\%)$ \\
\hline Tinggi & 16 & 32 \\
\hline Rendah & 34 & 68 \\
\hline Jumlah & 50 & 100 \\
\hline
\end{tabular}

Dari tabel di atas dapat diketahui bahwa sebagian besar responden berada pada tingkat pendidikan rendah yaitu 34 orang (68\%), sedangkan 16 orang (32\%) berada pada tingkat pendidikan tinggi.

b. Variabel tingkat sosial ekonomi (pendapatan)

Tabel 9

\begin{tabular}{ccc}
\hline $\begin{array}{c}\text { Tingkat } \\
\text { Pendapatan }\end{array}$ & $f$ & $(\%)$ \\
\hline Tinggi & 9 & 18 \\
\hline Rendah & 41 & 82 \\
\hline Jumlah & 50 & 100 \\
\hline
\end{tabular}

Dari tabel di atas dapat diketahui bahwa sebagian besar responden berada pada tingkat sosial ekonomi rendah yaitu 41 orang (82\%), sedangkan 9 orang (18\%) berada pada tingkat sosial ekonomi tinggi.

c. Variabel tingkat pengetahuan

Tabel 10

\begin{tabular}{ccc}
\hline $\begin{array}{c}\text { Tingkat } \\
\text { Pengetahuan }\end{array}$ & $\mathrm{f}$ & $\%$ \\
\hline Tinggi & 31 & 62 \\
\hline Rendah & 19 & 38 \\
\hline Jumlah & 50 & 100 \\
\hline
\end{tabular}

Dari tabel di atas dapat diketahui bahwa sebagian besar responden berada pada tingkat pengetahuan tinggi yaitu 31 orang (62\%), sedangkan 19 orang (38\%) berada pada tingkat pengetahuan rendah.

d. Variabel kejadian karies gigi Tabel 11

\begin{tabular}{ccc}
\hline $\begin{array}{c}\text { Kejadian Karies } \\
\text { Gigi }\end{array}$ & $\mathrm{f}$ & $\%$ \\
\hline Karies & 23 & 46 \\
\hline Tidak & 27 & 54 \\
\hline Jumlah & 50 & 100 \\
\hline
\end{tabular}

Dari tabel di atas dapat diketahui bahwa sebagian besar balita tidak mengalami karies gigi yaitu 27 orang (54\%), sedangkan 23 orang $(46 \%)$ mengalami karies gigi.

e. Hubungan tingkat pendidikan dengan kejadian karies gigi

Tabel 12

$\begin{array}{cc}\text { Tingkat } & \begin{array}{c}\text { Kejadian Karies } \\ \text { Pendidi }\end{array} \\ \text { Kan } & \text { Karies Tidak }\end{array}$

\begin{tabular}{cccc}
\hline Tinggi & 2 & 14 & 16 \\
\hline Rendah & 21 & 13 & 34 \\
\hline Jumlah & 23 & 27 & 50 \\
\hline
\end{tabular}

Berdasarkan tabel di atas dapat dilihat bahwa:

1) Terdapat responden yang mempunyai tingkat pendidikan tinggi yaitu 16 orang, dengan 2 balita yang mengalami karies gigi dan 14 balita tidak mengalami karies gigi.

2) Terdapat responden yang mempunyai tingkat pendidikan rendah yaitu 34 orang, dengan 21 balita yang mengalami karies gigi dan 13 balita tidak mengalami karies gigi. 
Berdasarkan hasil uji statistik bivariat dengan menggunakan chi square dengan $\alpha=5 \%$ $(0,05)$ diperoleh $p$ sebesar 0,001 sehingga $p<0,05$, yang berarti hipotesa diterima maka dapat ditarik kesimpulan bahwa ada hubungan tingkat pendidikan dengan kejadian karies gigi pada anak balita di Desa Mancasan.

f. Hubungan tingkat osial ekonomi dengan kejadian karies gigi

Tabel 13

\begin{tabular}{cc}
\hline Tingkat & \begin{tabular}{c} 
Kejadian Karies \\
Sosial \\
\cline { 2 - 2 } Ekonomi
\end{tabular} \\
\cline { 2 - 2 } & Karies Tidak
\end{tabular}

\begin{tabular}{cccc}
\hline Tinggi & 1 & 8 & 9 \\
\hline Rendah & 22 & 19 & 41 \\
\hline Jumlah & 23 & 27 & 50 \\
\hline
\end{tabular}

Berdasarkan tabel di atas dapat dilihat bahwa

1) Terdapat responden yang mempunyai tingkat sosial ekonomi tinggi yaitu 9 orang, dengan 1 balita yang mengalami karies gigi dan 8 balita tidak mengalami karies gigi.

2) Terdapat responden yang mempunyai tingkat sosial ekonomi rendah yaitu 41 orang, dengan 22 balita yang mengalami karies gigi dan 19 balita tidak mengalami karies gigi.

Berdasarkan hasil uji statistik bivariat dengan menggunakan chi square dengan $\alpha=5 \%$ $(0,05)$ diperoleh $p$ sebesar 0,02 sehingga $p<0,05$, yang berarti hipotesa diterima maka dapat ditarik kesimpulan bahwa ada hubungan tingkat sosial ekonomi dengan kejadian karies gigi pada anak balita di Desa Mancasan.

g. Hubungan tingkat pengetahuan dengan kejadian karies gigi

Tabel 14

\begin{tabular}{cccc}
\hline \multirow{2}{*}{$\begin{array}{c}\text { Tingkat } \\
\text { Pengetahua }\end{array}$} & \multicolumn{2}{c}{$\begin{array}{c}\text { Kejadian Karies } \\
\text { Gigi }\end{array}$} & \\
\cline { 2 - 3 } & Karies & Tidak & \\
\hline Tinggi & 9 & 22 & 31 \\
\hline Rendah & 14 & 5 & 19 \\
\hline Jumlah & 23 & 2 & 50 \\
\hline
\end{tabular}

Berdasarkan tabel di atas dapat dilihat bahwa

1) Terdapat responden yang mempunyai tingkat pengetahuan tinggi yaitu 31 orang, dengan 9 balita yang mengalami karies gigi dan 22 balita tidak mengalami karies gigi.

2) Terdapat responden yang mempunyai tingkat pengetahuan rendah yaitu 19 orang, dengan 14 balita yang mengalami karies gigi dan 5 balita tidak mengalami karies gigi.

Berdasarkan hasil uji statistik bivariat dengan menggunakan chi square dengan $\alpha=5 \%$ $(0,05)$ diperoleh $p$ sebesar 0,002 sehingga $p<0,05$, yang berarti hipotesa diterima maka dapat ditarik kesimpulan bahwa ada hubungan tingkat pengetahuan dengan kejadian karies gigi pada anak balita di Desa Mancasan. 
h. Hubungan tingkat pendidikan, tingkat sosial ekonomi dan tingkat pengetahuan dengan kejadian karies gigi

Tabel 15

\begin{tabular}{ccc}
\hline $\begin{array}{c}\text { Variabel } \\
\text { Independen }\end{array}$ & OR & $\mathrm{P}$ \\
\hline $\begin{array}{c}\text { Tingkat } \\
\text { Pendidikan }\end{array}$ & 0,133 & 0,035 \\
\hline $\begin{array}{c}\text { Tingkat Sosial } \\
\text { Ekonomi }\end{array}$ & 0,163 & 0,179 \\
\hline $\begin{array}{c}\text { Tingkat } \\
\text { Pengetahuan }\end{array}$ & 0,118 & 0,008 \\
\hline \multicolumn{3}{c}{ Nagelkerke R Square $47,3 \%$} \\
\hline
\end{tabular}

Hasil Analisa Multivariat Regresi Logistik Ganda Antara Tingkat Pendidikan, Tingkat Sosial Ekonomi dan Tingkat Pengetahuan Dengan Kejadian Karies Gigi

Berdasarkan tabel di atas dapat dilihat bahwa :

1) Adanya hubungan yang negatif dan signifikan antara tingkat pendidikan dengan kejadian karies gigi pada anak balita. Responden yang memiliki tingkat pendidikan tinggi mampu mencegah anak balitanya untuk mengalami karies gigi 13 kali lebih baik daripada responden yang memiliki tingkat pendidikan rendah. (OR $=0,133 ; p=0,035)$

2) Adanya hubungan yang negatif dan tidak signifikan antara tingkat sosial ekonomi dengan kejadian karies gigi pada anak balita. Responden yang memiliki tingkat sosial ekonomi tinggi mampu mencegah anak balitanya untuk mengalami karies gigi 16 kali lebih baik daripada responden yang memiliki tingkat sosial ekonomi rendah. $(\mathrm{OR}=$ 0,$163 ; p=0,179$ )
3) Adanya hubungan yang negatif dan signifikan antara tingkat pengetahuan dengan kejadian karies gigi pada anak balita. Responden yang memiliki tingkat pengetahuan tinggi mampu mencegah anak balitanya untuk mengalami karies gigi 11 kali lebih baik daripada responden yang memiliki tingkat pengetahuan rendah. $(\mathrm{OR}=$ $0,118 ; p=0,008)$

4) Bahwa hasil penelitian menunjukkan variabel independen secara bersama-sama mempengaruhi variabel dependen dapat dilihat pada nilai Nagelkerke $R$ Square $\quad 47,3 \%$ artinya bahwa variabel tingkat pendidikan, tingkat sosial ekonomi dan tingkat pengetahuan orangtua mampu mempengaruhi kejadian karies gigi pada anak balita sebesar $47,3 \%$ dan sisanya $52,7 \quad \%$ dipengaruhi oleh variabel lain di luar penelitian

\section{PEMBAHASAN}

1. Hubungan Tingkat Pendidikan dengan Kejadian Karies Gigi Pada Balita

Dari tabel 8 dapat diketahui bahwa sebagian besar responden berada pada tingkat pendidikan rendah yaitu 34 orang (68\%), sedangkan 16 orang (32\%) berada pada tingkat pendidikan tinggi.

Pendidikan sebagaimana yang dikutip oleh Malik (2013) adalah daya upaya untuk memajukan budi pekerti (karakter, kekuatan batin), pikiran (intellect), dan jasmani anak-anak selaras dengan alam dan masyarakatnya. Menurut Mill sebagaimana yang 
dikutip oleh Malik (2013), mengemukakan bahwa pendidikan itu meliputi segala sesuatu yang dikerjakan oleh seseorang untuk dirinya atau yang dikerjakan oleh orang lain untuknya, dengan tujuan mendekatkannya kepada tingkat kesempurnaan. Dari beberapa pengertian pakar pendidikan di atas kita dapat menarik benang merah bahwa pendidikan terkait dengan daya dalam proses pembentukan budi pekerti, pikiran, dan jasmani menuju tingkat kesempurnaan. Pendidikan terkait pula dengan proses pematangan intelektual, emosional, dan kemanusiaan yang dilakukan secara terusmenerus. Dengan demikian pendidikan diusahakan secara sadar melalui proses bimbingan, pengajaran dan latihan.

Dengan kata lain, pendidikan tak lain adalah proses memberikan pengaruh pada kebiasaan tingkah laku, pikiran, dan perasaan.

Dalam penelitian ini peneliti membuat kategori pendidikan menjadi dua yaitu tinggi dan rendah, berbeda dengan kategori pendidikan dalam UndangUndang No. 20 tahun 2003. sedangkan yang termasuk dalam kategori pendidikan tinggi dimulai dari sekolah menengah atas.

Dari uraian di atas maka bila dihubungkan dengan kejadian karies gigi, pada tabel 12. dapat dipaparkan bahwa responden yang mempunyai tingkat pendidikan tinggi yaitu 16 orang, hanya 2 balita yang mengalami karies gigi dan 14 balita tidak mengalami karies gigi, sedangkan responden yang mempunyai tingkat pendidikan rendah yaitu 34 orang, ada 21 balita yang mengalami karies gigi dan 13 balita tidak mengalami karies gigi.

Hasil di atas diperkuat dengan hasil uji statistik bivariat dengan menggunakan chi square dengan $\alpha=5 \%(0,05)$ diperoleh $p$ sebesar 0,001 sehingga $p<0,05$, dimana ada hubungan tingkat pendidikan dengan kejadian karies gigi pada anak balita di Desa Mancasan. Sebagaimana yang dikutip oleh Mubarak, et al. (2007), bahwa pendidikan erat kaitannya dengan pengetahuan. Di mana semakin tinggi tingkat pendidikan seseorang maka semakin banyak pula pengetahuan yang diperolehnya. Selain pendidikan ada faktor lain yang mempengaruhi antara lain pekerjaan, umur, minat, pengalaman, kebudayaan, dan informasi.

Lingkungan pekerjaan dapat menjadikan seseorang memperoleh pengalaman dan pengetahuan baik secara langsung maupun secara tidak langsung. Hal ini sejalan dengan pekerjaan responden yang sebagian besar adalah wiraswasta 18 orang (36\%), dari pekerjaan tersebut menunjukkan bahwa responden banyak berinteraksi dengan orang lain sehingga memberikan pengalaman dan pengetahuan kepada responden secara langsung.

Dari faktor umur, dengan bertambahnya umur seseorang akan terjadi perubahan pada fisik dan psikologis yang mampu mempengaruhi kemampuan seseorang dalam mencari informasi atau pengetahuan. Umur responden terbanyak adalah usia 25 - 30 tahun yaitu 26 orang (52\%), dimana umur tersebut tergolong dalam usia 
produktif sehingga responden mampu mencari informasi yang dibutuhkan dengan baik.

2. Hubungan Tingkat Sosial Ekonomi dengan Kejadian Karies Gigi Pada Balita

Dari tabel 9 dapat diketahui bahwa sebagian besar responden berada pada tingkat sosial ekonomi rendah yaitu 41 orang (82\%), sedangkan 9 orang (18\%) berada pada tingkat sosial ekonomi tinggi. Tingkat sosial ekonomi dalam penelitian ini berdasarkan pada tingkat pendapatan keluarga perbulan. Menurut Haryono dan Setianingsih (2014), pendapatan keluarga adalah penghasilan yang diperoleh suami dan istri dari berbagai kegiatan ekonomi sehari-hari, misalnya gaji.

Berdasarkan tabel 13 dapat dilihat bahwa responden yang mempunyai tingkat sosial ekonomi tinggi yaitu 9 orang, hanya 1 balita yang mengalami karies gigi dan 8 balita tidak mengalami karies gigi, sedangkan responden yang mempunyai tingkat sosial ekonomi rendah yaitu 41 orang, ada 22 balita yang mengalami karies gigi dan 19 balita tidak mengalami karies gigi.

Hasil di atas diperkuat oleh hasil uji statistik bivariat dengan menggunakan chi square dengan $\alpha=5 \%(0,05)$ diperoleh $p$ sebesar 0,02 sehingga $p<0,05$, yang berarti bahwa ada hubungan tingkat sosial ekonomi dengan kejadian karies gigi pada anak balita di Desa Mancasan.

Sebagaimana yang disampaikan oleh Prishardoyo, et al. (2005), faktor yang mempengaruhi pendapatan keluarga adalah jumlah pendapatan keluarga, jumlah dan usia anggota keluarga, tingkat harga barang dan jasa. Maka dengan hasil uji bivariat terdapat hubungan tingkat sosial ekonomi dengan kejadian karies gigi pada anak balita di Desa Mancasan menunjukkan faktor sosial ekonomi mampu mempengaruhi kejadian karies gigi.

3. Hubungan Tingkat Pengetahuan Tentang Perawatan Gigi dengan Kejadian Karies Gigi Pada Balita

Dari tabel 10 dapat diketahui bahwa sebagian besar responden berada pada tingkat pengetahuan tinggi yaitu 31 orang (62\%), sedangkan 19 orang (38\%) berada pada tingkat pengetahuan rendah.

Pengetahuan adalah hasil "tahu", dan ini terjadi setelah orang melakukan pengindraan terhadap suatu objek tertentu. Pengindraan terjadi melalui panca indera manusia, yakni indera penglihatan, pendengaran, penciuman, rasa dan raba. Sebagian besar pengetahuan diperoleh melalui mata dan telinga. (Fitriani, 2011)

Sebagian besar responden mempunyai tingkat pengetahuan yang tinggi. Tingkat pengetahuan seseorang dipengaruhi oleh beberapa hal yaitu pendidikan yang diterima dengan baik dari lingkungan sekolah, keluarga maupun dari orang lain. Bisa diperoleh melalui berbagai media informasi seperti buku, internet dan media massa yang lain. Semakin bertambah usia dan pengetahuan seseorang juga mempengaruhi pola pikir yang semakin berkembang. Hal ini sesuai dengan yang dikemukakan oleh Mubarak, et al. (2007), bahwa faktor-faktor yang mempengaruhi tingkat 
pengetahuan seseorang adalah pendidikan, pekerjaan, umur, minat, pengalaman, kebudayaan, dan informasi.

Berdasarkan tabel 14 dapat dilihat responden yang mempunyai tingkat pengetahuan tinggi yaitu 31 orang, hanya 9 balita yang mengalami karies gigi dan 22 balita tidak mengalami karies gigi sedangkan responden yang mempunyai tingkat pengetahuan rendah yaitu 19 orang, terdapat 14 balita yang mengalami karies gigi dan 5 balita tidak mengalami karies gigi.

Hal di atas di dukung oleh hasil uji statistik bivariat dengan menggunakan chi square dengan $\alpha=5 \%(0,05)$ diperoleh $p$ sebesar 0,002 sehingga $p<0,05$, yang bahwa ada hubungan tingkat pengetahuan dengan kejadian karies gigi pada anak balita di Desa Mancasan.

Pengetahuan atau kognitif merupakan domain yang sangat penting dalam membentuk tindakan seseorang (overt behavior). (Fitriani, 2011) Sedangkan menurut Notoatmodjo (2011), dari pengalaman dan penelitian ternyata perilaku yang didasarkan oleh pengetahuan akan lebih langgeng daripada perilaku yang tidak didasari oleh pengetahuan.

Hasil penelitian ini sesuai dengan penelitian Yulianti (2011) yang meneliti tentang hubungan pengetahuam orang tua tentang kesehatan gigi dan mulut dengan kejadian karies gigi pada anak di SDN $V$ Jaten Karanganyar dimana didapatkan hasil uji hipotesis diperoleh nilai $Z=1,435$ dan nilai $p$-value $=0,033$. P-Value $<0,05$, maka terdapat hubungan yang signifikan antara tingkat pengetahuan orang tua tentang kesehatan gigi dan mulut dengan kejadian karies gigi anak SDN V Jaten Karanganyar

4. Hubungan Tingkat Pendidikan, Tingkat Sosial Ekonomi dan Tingkat Pengetahuan dengan Kejadian Karies Gigi Pada Balita

Hasil penelitian menunjukkan variabel independen secara bersama-sama mempengaruhi variabel dependen. Hal ini dapat dilihat dari nilai Nagelkerke $R$ Square $47,3 \%$ analisis dengan model regresi logistik ganda. Variabel independen yang dimasukkan dalam model adalah tingkat pendidikan, tingkat sosial ekonomi dan tingkat pengetahuan secara bersamaan mampu mempengaruhi variabel dependen yaitu kejadian karies gigi, maka dapat disimpulkan bahwa variabel independen secara bersama-sama yaitu tingkat pendidikan, tingkat sosial ekonomi, tingkat pengetahuan berpengaruh terhadap variabel dependen yaitu kejadian karies gigi. Dari tabel 11 dapat diketahui bahwa sebagian besar balita tidak mengalami karies gigi yaitu 27 orang (54\%), sedangkan 23 orang $(46 \%)$ mengalami karies gigi.

Cara menggosok gigi anak-anak perlu diajarkan untuk menggosok gigi paling tidak setelah makan pagi dan terakhir pada malam hari. Gigi harus disikat dengan gerakan rol, mulai dari gusi kearah permukaan gigi dan sikat harus menembus celah di antara setiap gigi. Akan tetapi menjadi sulit bila gigi saling berdekatan, untuk itu ajarkan untuk menggunakan dental floss untuk menghilangkan plak gigi atau partikel makanan. (Sodikin, 2011)

Makanan mencegah karies gigi, pengurangan frekuensi 
mengkonsumsi karbohidrat dapat mencegah karies gigi, termasuk dalam hal ini konsumsi permen karet, gula-gula, dan minuman ringan yang mengandung gula (manitol, sorbitol, aspartam). Ahli gigi telah menganjurkan agar lebih banyak makan buah-buahan serta sayur-sayuran. Walaupun begitu, makanan yang menimbulkan keasaman dalam mulut, seperti apel, tidak dianjurkan untuk dikonsumsi pada waktu malam hari, hal ini merupakan langkah pencegahan yang efektif pada anak dengan gigi manis (sweet tooth). (Sodikin, 2011)

Untuk mengetahui semua hal di atas maka dibutuhkan pengetahuan yang cukup dalam hal perawatan gigi oleh orangtua, pengetahuan bisa diperoleh salah satunya dengan pendidikan, semakin tinggi pendidikan maka diharapkan semakin luas tingkat pengetahuannya, selain itu perlu dukungan finansial untuk mencapai kesehatan yang optimal. Dengan demikian tingkat pendidikan, tingkat sosial ekonomi dan tingkat pengetahuan merupakan faktor yang mempengaruhi kejadian karies gigi pada anak balita di Desa Mancasan.

\section{KESIMPULAN}

1. Didapatkan hasil frekuensi paling banyak pada tingkat pendidikan rendah yaitu 34 responden (68 \%), dan frekuensi tingkat pendidikan tinggi yaitu 16 responden (32\%)

2. Didapatkan hasil frekuensi paling banyak pada tingkat sosial ekonomi rendah yaitu 41 responden (82 \%), dan frekuensi tingkat sosial ekonomi tinggi yaitu 9 responden (18\%)

3. Didapatkan hasil frekuensi paling banyak pada tingkat pengetahuan tinggi yaitu 31 responden (68 \%), dan frekuensi tingkat pendidikan rendah yaitu 19 responden (28 $\%)$

4. Berdasarkan hasil uji analisa bivariat dengan menggunakan chi square dengan $\alpha=5 \%$ $(0,05)$ diperoleh $p$ sebesar 0,001 sehingga $p<0,05$ yang berarti hipotesa diterima maka dapat disimpulkan bahwa ada hubungan tingkat pendidikan dengan kejadian karies gigi pada balita di Desa Mancasan.

5. Berdasarkan hasil uji analisa bivariat dengan menggunakan chi square dengan $\alpha=5 \%$ $(0,05)$ diperoleh $p$ sebesar 0,020 sehingga $p<0,05$ yang berarti hipotesa diterima maka dapat disimpulkan bahwa ada hubungan tingkat sosial ekonomi dengan kejadian karies gigi pada balita di Desa Mancasan.

6. Berdasarkan hasil uji analisa bivariat dengan menggunakan chi square dengan $\alpha=5 \%$ $(0,05)$ diperoleh $p$ sebesar 0,002 sehingga $p<0,05$ yang berarti hipotesa diterima maka dapat disimpulkan bahwa ada hubungan tingkat pengetahuan dengan kejadian karies gigi pada balita di Desa Mancasan.

7. Berdasarkan hasil uji analisa multivariat menunjukkan bahwa variabel independen secara bersama-sama mempengaruhi variabel dependen yang mana dapat dilihat pada nilai Nagelkerke R Square 47,3 \% artinya bahwa variabel tingkat pendidikan, tingkat sosial ekonomi dan tingkat pengetahuan secara bersamasama mampu mempengaruhi kejadian karies gigi pada anak balita sebesar 47,3 \% dan sisanya $52,7 \%$ dipengaruhi variabel lain di luar penelitian. Jadi terdapat hubungan antara 
tingkat pengetahuan, tingkat sosial ekonomi dan tingkat pengetahuan tentang perawatan gigi dengan kejadian karies gigi padaanak balita di Desa Mancasan.

\section{SARAN}

1. Sesuai hasil penelitian bahwa terdapat hubungan antara tingkat pendidikan, tingkat sosial ekonomi dan tingkat pengetahuan tentang perawatan gigi dengan kejadian karies gigi pada anak balita, maka hasil penelitian ini dapat memberikan motivasi pada orangtua yang memiliki tingkat pendidikan kategori rendah untuk meningkatkan pengetahuan dengan cara membaca atau mencari informasi tentang perawatan gigi melalui cara lain agar bisa melakukan pencegahan terhadap kejadian karies gigi.

2. Sedangkan bagi keluarga dengan tingkat sosial ekonomi kategori rendah untuk berusaha menyediakan perawatan gigi minimal bagi balitanya dengan cara menyediakan sikat gigi dan pasta gigi yang sesuai dengan usia anak.

3. Orangtua diharapkan senantiasa memperhatikan kebersihan gigi anak dengan cara mengajari menggosok gigi setiap kali selesai makan dan menjelang tidur malam.

\section{DAFTAR PUSTAKA}

Ariani, Ayu Putri. 2014. Aplikasi Metodologi Penelitian Kebidanan dan Kesehatan Reproduksi. Nuha Medika, Yogyakarta.

Budiyanti, Arlia. 2006. Perawatan Endodontik pada Anak. EGC, Jakarta.
Fitriani, Sinta. 2011. Promosi Kesehatan. Edisi I. Graha Ilmu, Yogyakarta.

Hidayat, A. Aziz Alimul. 2009. Metodologi Penelitian Keperawatan dan Teknik Analisis Data. Jakarta: Salemba Medika.

. 2008. Riset Keperawatan dan Teknik Penulisan IImiah. Edisi II. Salemba Medika, Jakarta.

Mansjoer, Arif. 2001. Kapita Salekta Kedokteran. Media Aesculapius FKUI, Jakarta.

Maulani dan Jubilee. 2005. Panduan Orang Tua Dalam Merawat dan Menjaga Kesehatan Gigi Bagi Anaknya. PT. Elex Media Komputindo Gramedia, Jakarta.

Mubarak, et al. 2007. Promosi Kesehatan Sebuah Pengantar Proses Belajar Mengajar dalam Pendidikan. Graha IImu, Yogyakarta.

Notoatmodjo, Soekidjo. 2012. IImu Perilaku Kesehatan. Rineka Cipta, Jakarta.

Nursalam. 2013. Metodologi Penelitian IImu Keperawatan. Edisi III. Salemba Medika, Jakarta.

Sodikin. 2011. Asuhan Keperawatan Anak: Gangguan Sistem Gastrointestinal dan Hepatobilier. Salemba Medika, Jakarta.

Susanto. 2007. Kesehatan Gigi dan Mulut. Sunda Kelapa Pustaka, Jakarta, 
Trisnawati dan Arroyyan Dwi Andini. 2011. Gigi Sehat Ibadah Dahsyat. Penerbit: Pro-U Media, Yogyakarta.

Nugroho, Tomi Adi. 2004. "Hubungan Tingkat Pengetahuan Dan Perilaku Orang Tua Tentang Pemberian Susu Botol Dengan Kejadian Karies Gigi Pada Siswa Prasekolah Intan Permata, Di Desa Makamhaji, Kecamatan Kartosuro, Kabupaten Sukoharjo". URL: eprints.ums.ac.id/22019/13/NA SKAH_PUBLIKASI.pdf.

Yulianti, Riska Puji. 2011. "Hubungan pengetahuan orang tua tentang kesehatan gigi dan mulut dengan kejadian karies gigi pada anak di SDN V Jaten, Karanganyar". URL:

eprints.ums.ac.id/14779.pdf. Diakses tanggal 4 Januari 2016.
Wahyuni. 2010. "Perawatan Gigi dan Mulut Pada Masa Balita dan Anak".

URL: http://www.Balita_anda.com/fat herhood/339.htm.

Diakses tanggal 5 Desember 2015.

1 Dosen AKPER Panti Kosala Surakarta

2 Mahasiswa AKPER Panti Kosala Surakarta 